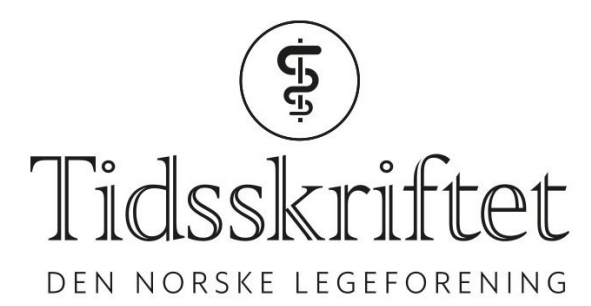

\title{
Når jusen kommer i veien for kommunikasjonen
}

LEDER

\section{ANNE HØYE}

E-post: anne.hoye@unn.no Anne Høye er psykiater, professorstipendiat ved Institutt for klinisk medisin (IKM) ved Universitetet i Troms $\emptyset$ - Norges arktiske universitet, og overlege ved Psykiatrisk avdeling, Psykisk helse- og rusklinikken, Universitetssykehuset Nord-Norge.

Forfatter har fylt ut ICMJE-skjemaet og oppgir ingen interessekonflikter.

\section{SIREN HOVEN}

Siren Hoven er psykiater og avdelingsleder for Psykiatrisk avdeling ved Psykisk helse- og rusklinikken, Universitetssykehuset Nord-Norge.

Forfatter har fylt ut ICMJE-skjemaet og oppgir ingen interessekonflikter.

Språket former hvordan vi tenker - og handler. Har kravene til journalspråket fjernet oss fra pasientene?

Godt fagspråk og presise begreper er viktig og nødvendig for å kunne belyse og ivareta etiske dilemmaer i psykisk helsevern, ettersom språket former måten vi tenker på, men også hva vi prioriterer (1). Teknologisk utvikling, økt brukermedvirkning og rett til innsyn har sannsynligvis hatt flere positive effekter på pasientjournalen, som mindre bruk av fremmedgjørende språk og mer respektfull omtale av pasienten. Krav til juridisk dokumentasjon gir etter alt å dømme økt rettssikkerhet, men dette innebærer ikke nødvendigvis god behandling eller god kommunikasjon. Kan behovet for å ha juridisk ryggdekning faktisk fjerne oppmerksomheten fra pasienten?

Lingvisten Dariusz Galasiński har påpekt at alle former for kommunikasjon er målrettet og avhengig av kontekst (2). Uansett om vi forteller en god historie, stiller spørsmål, informerer eller dokumenterer, har vi et formål med det vi kommuniserer. Han tar til orde for at klinisk kommunikasjon bør reflektere hvilket formål man har og i mindre grad være sentrert rundt hvilke faktiske spørsmål som skal stilles. I forlengelsen av dette: Hva er hovedformålet med journalen? Kommunikasjon med andre behandlere? Med pasient og pårørende? Eller er hovedformålet mer defensivt - å dokumentere at lovverk og retningslinjer er fulgt i tilfelle man skulle bli kikket i kortene?

Professor Aslak Syse har i en leder i Tidsskriftet skrevet om den sentrale forskjellen mellom medisinsk og juridisk tenkemåte: Medisinen skal være til nytte for den enkelte (formålsrasjonalitet), mens jusen skal forsøke å generalisere ved å utforme regler som skal gjelde i de fleste tilfeller (normrasjonalitet) (3). Begge tenkemåter er fruktbare, men det er en iboende konflikt mellom dem. 
Innenfor psykisk helsevern forholder vi oss daglig til begge former for rasjonalitet, sannsynligvis mer direkte enn innenfor andre medisinske fagfelt. Vi skal hver dag behandle enkeltmennesker med sine helt personlige og individuelle behov, samtidig som vi ofte står i vanskelige etiske dilemmaer knyttet til pasientautonomi og bruk av tvang (4). Både juridisk og medisinsk tenkemåte kommer til uttrykk i lover og forskrifter. Dette medfører at selve behandlingsspråket, også i pasientjournalene, etter hvert har blitt innvevd med juridisk terminologi. Kliniske begreper benyttes også mer i lovtekstene. Denne endringen har nok skjedd trinnvis i takt med detaljeringsgraden i lovverket, men etter at viktige, prinsipielle endringer i lov om psykisk helsevern trådte i kraft 1. september 2017 (4), ser vi etter vår mening klare tegn til en markert økt «juridifisering» av språket.

Den tydeligste endringen i loven innebærer at pasienter med samtykkekompetanse gis rett til å nekte behandling i psykisk helsevern. Hensikten med lovendringen er å bringe kriteriene for psykisk helsehjelp nærmere hovedprinsippene om pasientens selvbestemmelsesrett og vilkår om samtykke før helsehjelpen ytes (5). Kravet til vurdering av samtykkekompetanse er omfattende, og tilsvarende har omfanget av anbefalinger for dokumentering av vurderingene vokst. Det er uunngåelig at vurderingene formuleres innenfor juridisk terminologi, dette påvirker både språklig kompleksitet og antall ord.

Når formålet er uklart, vil fagspråket vi benytter etter hvert gli over i formuleringer forsøkt tilpasset et juridisk formål, fordi kravene til språk og dokumentasjon her er mest normerende og tydeligst formulert. Klinikere er jo ikke jurister, og språket blir sannsynligvis både dårligere, mer omstendelig og gjentagende.

Vi mener det er en åpenbar fare for at vi mister journalens hovedformål av syne, nemlig kommunikasjon om selve behandlingen av pasienten. Hovedformålet med journalføringsplikten er å sikre at opplysninger som er nødvendige og relevante for forsvarlig behandling blir nedtegnet og kan gjenfinnes (6). Innholdet bør gi best mulig dokumentasjonsstøtte for god helsehjelp og kommunikasjon rundt denne.

Journalen er et av de viktigste arbeidsverktøyene vi behandlere har. Når journalspråket virker fremmedgjørende, undergraves journalen som kommunikasjonskanal, både mellom behandlere og mellom behandler og pasient /pårørende. Juridisk språk gjør heller ikke journalen mer tilgjengelig og forståelig for den det til syvende og sist handler om, nemlig pasienten.

LITTERATUR:

1. Whorf BL, Carroll JB red. Language, Thought and Reality: Selected Writings of Benjamin Lee Whorf. Cambridge, Massachusetts: Technology Press of Massachusetts Institute of Technology, 1956:5.

2. Galasiński D. Language and psychiatry. Lancet Psychiatry 2018; 5: 200 - 1. [PubMed][CrossRef]

3. Syse A. Om medisinsk etikk, medisin og jus. Tidsskr Nor Lægeforen 2007; 127: 1626. [PubMed]

4. LOV-1999-07-02-62. Lov om etablering og gjennomføring av psykisk helsevern (psykisk helsevernloven). https://lovdata.no/dokument/NL/lov/1999-07-02-62 (23.6.2018).

5. Helsedirektoratet. Psykisk helsevernloven og psykisk helsevernforskriften med kommentarer. https://helsedirektoratet.no/retningslinjer/psykisk-helsevernloven-og-psykisk-helsevernforskriften-m ed-kommentarer (23.6.2018).

6. Helsedirektoratet. Helsepersonelloven med kommentarer. Kapittel 8.

https://helsedirektoratet.no/retningslinjer/helsepersonelloven-med-kommentarer/seksjon?Tittelkapittel-8-dokumentasjonsplikt-11475\#§-39-plikt-til-å-føre-journal (23.6.2018).

Publisert:3. september 2018. Tidsskr Nor Legeforen. DOI: 10.4045/tidsskr.18.049o

(C) Tidsskrift for Den norske legeforening 2020. Lastet ned fra tidsskriftet.no 